\title{
The Effect of Leadership Styles on Firm Performance in Ghana
}

\author{
Albert Puni ${ }^{1}$, Samuel B. Ofei ${ }^{1} \&$ Abednego Okoe ${ }^{1}$ \\ ${ }^{1}$ Faculty of Management, University of Professional Studies, Accra, Ghana \\ Correspondence: Albert Puni, Faculty of Management, P. O. Box LG 149, University of Professional Studies, \\ Accra, Ghana. E-mail: albertpuni2000@yahoo.co.uk
}

Received: October 8, $2013 \quad$ Accepted: November 10, $2013 \quad$ Online Published: January 22, 2014
doi:10.5539/ijms.v6n1p177

\begin{abstract}
This research examines the effect of leadership on financial performance of two Ghanaian banks. The autocratic, democratic and laissez-faire leadership styles theories have been extensively discussed. Correlational research design was employed to determine the predictive relationship between the independent variables (autocratic, democratic and laissez-faire leadership styles) and the dependent variable (financial performance). Multiple Regression test was used to test the hypothesis in the study. The result showed that, none of the leadership styles significantly predicted financial performance of the two banks. However, democratic leadership style $(\beta=-.222)$ was found to account for more variance in financial performance than autocratic $(\beta=-.043)$ and laissez-faire $(\beta=-.039)$. The implications for practice and theory have been discussed.
\end{abstract}

Keywords: leadership style, firm performance

\section{Introduction}

Leadership style is one of the most important human resource-related outcomes, and perhaps one of the most studied topic in management and industrial psychology. This is probably so because leadership happens to be the core but sometimes contentious issue in organizational research (Hogan, Curphy, \& Hogan, 1994; House \& Aditya, 1997; Judge \& Piccolo, 2004; Khurana, 2002; Meindl, 1990). Leadership enables organizations to be more productive and profitable, but the extent of success depends on the style of the leader and the resultant environment created for employees to function well.

Kim (2004) is of the view that the kind of leadership style exhibited by managers to a large extent influences organizational valued outcomes such as low employee turnover, reduced absenteeism, customer satisfaction, and organizational effectiveness. Similarly, leadership style controls interpersonal, reward and punishment that shapes employee behaviour, motivation and attitude which impacts on organizational performance (Warrick, 1981). It can either lead to inspiration or disenchantment among employees resulting in increase or decrease productivity (Sander, 2007). Furthermore leadership style at the workplace can affect employee's self-image either positively or negatively particularly an employee's health and energy level by creating a stimulating work climate or one filled with tension or fear (Warrick, 1981).

The debate over whether leadership style can lead to firm performance has largely been contested. Those who support the veracity and efficacy of leadership style and firm performance believe that the disposition of leaders, their roles and responsibilities in decisions-making assist organizations to find solution to challenges and adapt to the complex competitive environment which impact on profitability (Bass, 1991; Waldman \&Yammarino, 1999). The literature revealed that without good decisions organizations would lack competitive advantage. In contrast, other theorists believe that organizations which are less endowed resourcefully are so disadvantaged that on its own leadership is too weak to influence performance except through the combination of several factors (Hanna \& Freeman, 1989; Meindl, 1990). Though the view seems reasonable, empirically, evidence suggested that leadership plays limited distinguishing role in influencing organizational members towards firm performance are scanty (Barrick, Day, Lord, \& Alexander, 1991; Bass, Avolio, Jung, \&Berson, 2003; Bertrand \&Schoar, 2003; Judge \& Piccolo, 2004; Judge, Piccolo, \&Ilies, 2004; Koene, Vogelaar, \&Soeters, 2002).

The literature on leadership and firm performance has concentrated on leadership and employee satisfaction, participative leadership style on job satisfaction, link between diversity and firm performance, female style in corporate leadership and managerial style on firm policies (Gordon, 1998; Bertrand et al. 2003; Belonia, 2012; Hamidifar, 2009; Warrick, 1981; Wright \& Stepp, 2006; Matsa \& Miller, 2011). Significantly, many of the 
studies concentrated on a single leader either the CEO, General Manager or Supervisor but organizational effectiveness depends on multiple leadership contributions (Hunt, 1991; O'Reilly et al. 2009). From the authors observations there are no empirical Ghanaian based findings on the predictive relationship between leadership styles and financial performance of banks. Since leadership style is not a product of one leader, investigating the dominant leadership style in an organization and how it has affected performance would expand the frontiers of the study of leadership and firm performance especially in Ghana.

\section{Purpose of Study}

The main purpose of this study is to examine the leadership styles of two Ghanaian banks and how they affect performance.

\section{Literature Review}

\subsection{Leadership Theories}

Organizations have been with humanity more that two centuries but despite the perceived influence of leadership on organizational performance, empirical research into leadership only commenced in the 1900s. Since the generation of interest in the concept, the body of knowledge has been growing fast with some over 350 definitions on the subject matter (Hamidifar, 2009).

To offer a comprehensive definition which encapsulates all leadership attributes would be very difficult (Bass, 1985), but the basic tenets of leadership are about influencing relationships among leaders and followers which generates effective behavior toward reaching defined organizational goals and objectives (Bennis \& Nanus, 1985; Burns 1978). Yukl (1994) pointed out that leadership is a process of having remarkable influence on the subordinate in which he or she is motivated to achieve a specified target and beyond, the group maintain cooperation and achieve stated objectives. Fry (2003) is also of the view that leadership is a strategic process of offering inspiration to enhance the employee's potential for growth and development by the leader. Northouse (2004) asserts that leadership is where any individual influences a group of people to achieve common goals.

The contribution by these researchers to the concept of leadership points to the fact that leadership is a positive but persuasive (influential) action which generates inspiration among followers and directs effort towards accomplishing specified individual, team, and organizational objectives. Leadership is indispensable; it is needed in business, political, educational, and social organizations for the attainment of goals (Bennis \&Nanus, 1985; Burns, 1978).

\subsection{Leadership Style Theories}

Several views have been expressed on leadership but most leadership theorist agree that the traits, style, and contingency theories dominate the leadership literature (Muller, 2005; House, 1971). The leadership style movement started in 1945 at the Ohio State University. Significantly, the "Consideration" and "Initiating Structure" study stood out from these early contributions which provided the basic dimensions of leadership behaviour in formal organizations.(source) Consequently, contributors like Kahn, Likert, Katz, Maccoby also expanded the works of their predecessors by basically analyzing the relationship between supervisory behaviour and employee productivity and satisfaction in 1947 at the University of Michigan. Their studies identified two styles of leadership - Employee Centered (EC) and Production Centered (PC) leadership. EC leaders focus more on employee goals and satisfaction and less time in performing similar task assigned to employees. It is also disinterested in punishing employees when they go wrong. On the other hand, PC leaders are interested in output therefore spend more time in actual supervisory work related to production and less attention on supervisory activities like planning.

\subsubsection{Autocratic Leadership Style}

Autocratic Leadership Style (ALS) places more emphasis on performance and low emphasis on people. The focus of power is with the leader and all interactions within the group move towards the leader (Mullins, 1999). The leader unilaterally exercises all decision-making authority by determining policies, procedures for achieving goals, work task, relationships, control of reward, and punishment (Mullins, 1999).

The basic assumption underlying autocratic leadership style is based on the premise that, people are naturally lazy, irresponsible, and untrustworthy and leaving the functions of planning, organizing, and controlling to subordinate would yield fruitless results and so such functions should be accomplished by the leader without the involvement of people. McGregor (1960) described the autocratic leader as the Theory X manager with the same set of theoretical assumptions as Taylor's scientific management and Schein's (1988) rational-economic model. Further, Likert's (1961) four management systems, characterized autocratic leadership style system as an 
exploitative-authoritative system where power and direction come from the top downwards, where threats and punishments are employed, and where communication is poor and team-work is non-existent (Cole, 2004). Tannenbaum and Schmidt (1957) described an autocratic leadership style on a continuum and opined that autocratic leaders make decisions and announce them, without inviting suggestions from subordinates.

Warrick (1981) concurs that autocratic leader relies heavily on authority, control, power, manipulation and hard work to get the job done. In the autocratic leadership system, formal centralized structures, procedures, processes and mechanism are clearly defined and are enforced to ensure that subordinates do their jobs efficiently within the rules. Punishments are often applied when mistakes are made and sanctions are in the form of withholding attention or good assignment or making people feel guilty. Motivation under this leadership style is by the means of economic incentives which are extrinsic in nature and based on performance. Development within an autocratic system comes from hard work and rarely does delegation of authority practiced.

Most theorists have identified autocratic leaders with authoritarian leaders simply because research has proven that there is a strong positive correlation between autocratic leadership style and authoritarianism (Bass, 1990; Choi, 2007; White \& Lippitt, 1960). Authoritarian leaders depend on their power as weapon for coercion. Although ALS is characterized with high productivity it often results in counter resistance of opposition which restricts output. The increase in productivity happens when the leader is present and the leadership style improves worker performance in relatively simple tasks (Gustainis, 2004).Warrick (1981) opine that ALS breeds hostile attitude, conflicts, distorts and guards communication, high turnover, absenteeism, low productivity, and affects work quality. The style also breeds yes-men who lack creativity and innovation and all they know is the adherence to rules, procedure, red-tape, and status seeking symbols and often afraid of taking responsibility because by doing so they risk committing punishable mistakes that would lead to demotion.

\subsubsection{Democratic Leadership Style}

Mullins (1999) is of the view that democratic leadership style focuses more on people and there is greater interaction within the group. The leadership functions are shared with members of the group and the leader is more part of the team (Mullins, 1999). Similarly, Luthar (1996) and Wilson et al. (1994) concurred that the principles of democratic leadership is friendliness, helpfulness, and the encouragement of participation. In the same vein, McGregor (1960) described this leadership style as benevolent, participative, and believing in people. He equated democratic leader to the Theory Y manager which is associated with increased follower productivity, satisfaction, involvement, and commitment (Hackman, Johnson, \& Choi, 2007).

The philosophical assumption underlying democratic leadership style is that naturally all people are trustworthy, self-motivated, like responsibility and challenging work and so encourages organizational conditions to foster teamwork, high performance and satisfaction (Warrick, 1981). The emphasis of this leadership style is on performance and people.

Based on the theoretical explanation of democratic leadership style, the researchers find that planning within a democratic leadership system is accomplished with heavy employee involvement with objectives that are transparently and clearly established with its accompanying performance targets. Decision-making in a democratic system is decentralized and flexible with clearly defined responsibilities and an open participative work environment. Punishments as a form of reprimand are the last option and high performance is recognized and rewarded. Conflicts are openly confronted by addressing the causative factors and not personalities.

Democratic leadership style results in high employee productivity, satisfaction, cooperation, and commitment. It reduces the need for controls and formal rules and procedures which result in low employee absenteeism and turnover. The leadership style develops competent and committed employees who are willing to give their best, think for themselves, communicate openly, and seek responsibility (Bass, 1990; Stogdill, 1974). With all the positive attributes associated with democratic leadership style, decision-making becomes over-stretched since opinions and lengthy debates play a key part in the process (Denhardt \& Denhardt, 2003).

\subsubsection{Laissez Faire Leadership Style}

The main emphasis of this leadership style is neither on performance nor people. The philosophical assumption is that naturally human beings are unpredictable and uncontrollable and trying to understand people is a waste of time and energy. On this hypothesis, the leader tries to maintain a low profile, respects all constituencies within the organization, tries not to create waves of disturbance, and relies on the few available loyalists to get the job done.

Laissez-faire leader lives and work with whatever structure put in place without any suggestions or criticisms. Goals and objectives are established only when necessary and required. The leader is not control-frisk and 
abdicates controlling to employees. He or she shuns decision-making as much as possible and would like to avoid communication but communicates only when needed (source). Thus, the business of employee development is not a concern to the laissez faire leader who believes that employees can take care of themselves.

\subsection{Leadership and Firm Performance}

Many of the early studies on leadership and firm performance concerted on exploring personality traits of successful leaders and how it contributes to firm performance (Argyris, 1955; Mahoney et al., 1960). These studies presume that successful leaders are naturally "born" with certain special inner qualities that make them different from their followers (Stodgill, 1948). However the challenge with this approach is the several criticisms leveled against it due to the inconsistency in the personality traits which characterize leaders leading to the emergence of the style and behavioural approaches to leadership (Stodgill, 1948).

The style and behavioural movement shifted the emphasis away from the characteristics of the leader to the behaviour and style the leader adopted (Hemphill \& Coons, 1957; Likert, 1961). Major findings from the style approach suggested that leaders who appeared to have adopted democratic or participative leadership style are more successful than their counterparts who are more autocratic or laissez faire (Bowsers \& Seashore, 1966). Again the shortfall of the style approach is its failure to recognize the context within which the leader is operating (Mullins, 1999). This difficulty culminated into the emergence of the situational or the contingency theories of leadership which directed leadership from the "one-best" way approach to situational-sensitive leadership (Fiedler, 1967; House, 1971; Vroom \& Yetton, 1974). The foundation of the contingency leadership approach is anchored on the leader's ability to analyze the situation at hand and appropriately adopting a suitable style which best suites the circumstance.

In contemporary times, the emphasis of leadership research has shifted from the "one-best" way approach to transformation and transactional leadership which turn to differentiate the type of leadership through the style adopted and the results achieved. Transactional leaders are said to be 'instrumental' and frequently focus on exchange (Ogbonna \& Harris, 1993). However, it is argued that transformational leaders are visionary and enthusiastic, with an inherent ability to motivate subordinates (Bycio et al., 1995; Howell \& Avolio, 1993). A number of researchers theorize that transformational leadership is linked to organizational performance (Bycio et al., 1995; Howell \& Avolio, 1993).

Using the above distinction, Fiedler (1996) argued that the effectiveness of leadership to a large extent is responsible for organizational performance. Similarly, others writers that one way in which organizations are able to cope with the increasing volatility and turbulence of the external environment is by training and developing leaders and equipping them with the skills to cope (Darcy \& Kleiner, 1991; Hennessey, 1998; Saari et al., 1988). Indeed the argument of effective leadership is not limited to firm success but also extends to nations. Notable empirical researches that have linked effective leadership to firm performance can be cited in the works (Nicholls, 1988; Quick, 1992; Simms, 1997; Thorlindsson, 1987). Prominent among these is the exceptional study conducted by Thorlindsson, (1987) on sank ships in the Icelandic, which revealed that the leadership qualities of the ship captains accounted for 35 to 49 per cent of variation in the catch of different crews. In précis, the above evidence point to the fact that leadership is responsible for firm performance, but the question of style which generates maximum performance leave much to be desired.

Predictors

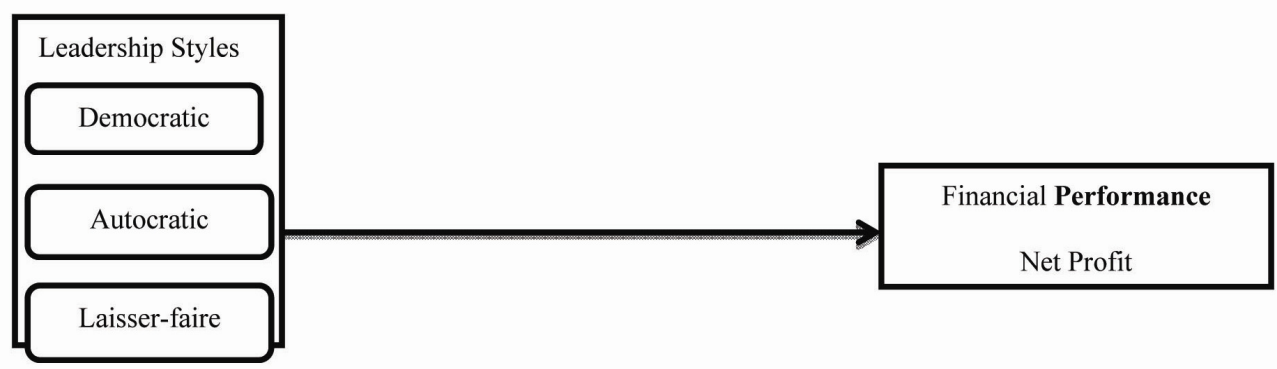

Figure 1. Conceptual model of the predictive relationship between leadership styles and financial performance Authors Construct 2013 


\section{Methodology}

\subsection{Research Design}

Predictive correlational research design was utilized to determine the predictive relationship between the independent variables (democratic, autocratic and laisser-faire leadership styles) and dependent variable (financial performance). The study was purely quantitative because reliable questionnaire was used to collect data.

\subsection{Sample Size and Sampling Techniques}

Non-probability sampling strategies were used to select the banks and participants. Convenience and purposive sampling strategies were utilized. The banks were selected conveniently as only banks that were interested in the study were selected. However, since the researchers were interested in the leaders in the organization, purposively, they were selected. Thus, employees in the selected banks who were within managerial ranks were target.

\subsection{Research Instrument}

The leadership style scale developed by Simon Oates (2010) was used to measure the three leadership styles in the study. It is a 12-item scale measuring three leadership styles, autocratic (4-items), democratic (4-items), and laisser-faire (4-items). The items were anchored on 5-point Likert scale ranging from strongly disagree (0) to strongly agree (4). The minimum and maximum score on each of the leadership style scale ranges from 0 to 16 with 0 indicating lack of a particular leadership style.

Financial performance was measured using net profit figures from 2009 to 2011. This data was sourced from annual reports of the two banks involved in the study.

\subsection{Data Collection Procedure}

To satisfy the ethical principle of institutional approval, the researchers sought permission through the Human Resource Department of the selected banks. The purpose of the study was clearly explained to them to enable them arrive at an informed decision. A sample questionnaire was given to the Human Resource Department of these banks to enable them know the kind of information required for the study.

After permission was granted, the researchers proceeded to administer the questionnaires. The questionnaires were delivered by hand. To guarantee confidentiality of information provided, envelops were attached to the questionnaires and participants were instructed to put completed questionnaires into the envelops and seal them. This precaution was to ensure that the responses were privy only to the researchers.

\section{Results}

The study sought to determine the predictive relationship and amount of variance in financial performance accounted for by three different leadership styles: autocratic, democratic, and laisser-faire. The analysis was facilitated by the Statistical Product and Services Solution (SPSS) version 20.0. The analysis was in two parts. The first part which constituted the preliminary analysis sought to test some key assumptions underlying the use of regression analysis such as multicollinearity, collinearity and normality and the second part involved test of hypothesis.

\subsection{Preliminary Analysis}

Pearson correlation test was used to test some key assumptions underlying regression analysis. This test was particularly used to determine the existence or otherwise of multicollinearity. According to Tabachnick and Fidell (1996), two variables are said to be highly correlated (multicorrelated) when the correlation coefficient between them is \pm .70 and above. The bivariate correlation results in Table 1 show that, the correlation coefficient values between the leadership styles are below the threshold of \pm .70 . For instance, the correlation between democratic and autocratic is -.437; democratic and laisser-faire is .177, and autocratic and laisser-faire is .289. Also, collinearity statistics was conducted to determine the existence of multicollinearity. The result of this test showed that, the predictors are not multicorrelated as the values for the three predictors: democratic (.765), autocratic (.785) and laisser-faire (.940) are quite respectable. Because tolerance values near 0 suggest the possibility of multicollinearity. 
Table 1. Correlation matrix between leadership styles and financial performance

\begin{tabular}{lllll}
\hline Measures & 1 & 2 & 3 & 4 \\
\hline Democratic Leadership & - & & & \\
Autocratic Leadership & -.437 & & \\
Laisser-faire Leadership & .177 & .289 & -.081 & \\
Financial Performance & -.210 & .051 & \\
\hline
\end{tabular}

\subsection{Test of Hypothesis}

The study sought to determine the predictive relationship and amount of variance in financial performance accounted for by the three leadership styles (democratic, autocratic and laisser-faire) investigated. Standard multiple regression test was utilized. The results are presented in Table 2.

Table 2. Standard multiple regression of the predictive relationship between leadership styles and financial performance

\begin{tabular}{lllll}
\hline Model & & B & SE $\beta$ & $\beta$ \\
\hline 1 & (Constant) & 102933975.7 & 170086894.8 & \\
& Democratic & -2679165.731 & 6739010.156 & -.222 \\
& Authoritative & -671037.208 & 8596964.202 & -.043 \\
& Laisser-faire & -625868.884 & 8115706.617 & -.039 \\
\hline
\end{tabular}

As shown in Table 2, no statistically significant predictive relationship was observed between the three leadership styles and financial performance. Thus, the conceptual model in the study which indicated that, the three leadership styles or at least democratic leadership style will significantly predict financial performance was not supported $[\mathrm{F}(3,7)=.067, \mathrm{p}=.975]$. Though, a significant predictive relationship was not obtained, in terms of unique contribution, democratic leadership style $(\beta=-.222)$ accounted for more variance in financial performance than autocratic $(\beta=-.043)$ and laisser-faire $(\beta=-.039)$.

\section{Discussion}

Indicating from the result it can be argued that though there is no statistical significant prognostic relationship between the independent variables represented by autocratic, democratic, and laissez faire) and financial performance represented by net profit it is evident that democratic leadership style contributed significantly to financial $(\beta=-.222)$ than the autocratic and laissez faire leadership styles. The result is not surprising because theoretically, democratic leadership style focuses on people, by empowering and involving them in decision-making. Because followers feel part of the decision making process they become committed toward executing task associated with the decisions they were part of thereby resulting in high employee productivity (Choi, 2007). Clearly managers in the two banks are more democratic in their leadership approach because they believe that the caliber of workers they are dealing with are self-motivated, like responsibility and challenging work, and by involving them in decision-making process can build strong team sprit, high performance and satisfaction. The finding indicating a higher democratic $\beta$ value is a theoretical confirmation of McGregor (1960) theory Y manager whose leadership style generates high motivated followership and performance.

Empirically, the result is consistent with (Nicholls, 1988; Quick, 1992; Simms, 1997) which establishes that democratic leadership is associated with financial performance due to the co-operative atmosphere created among leaders and followers. The above evidence also presents a supporting claim that democratic leaders are often transformational because transformational leaders are visionary and enthusiastic, with an inherent ability to motivate subordinates towards high performance (Bycio et al., 1995; Howell \& Avolio, 1993). Though few studies have responded to the observation of Porter and Mckibbin (1988) that much of the research reported as supporting this claim is either inconclusive or empirically suspect, there is no doubt that transformational and democratic leadership can create committed and inspired followership that result in financial performance.

Also the low $\beta$ value ( $\beta=-.043$ ) for autocratic leadership style is an indication that managers perceive the style to be inappropriate for a service industry because the style breeds disenchantment and low motivated staff which leads to poor service delivery and non-competitiveness. Though theoretically autocratic leadership style generates high output, performance turn to be short-lived since employees become detached from the decision-making process, the sense of belonging and cohesion expected from them is lost. Similarly, a much 
lower $\beta$ value ( $\beta=-.039)$ for laissez faire leadership style from the result is an indication that leaders in the two banks do not accept the philosophical assumption that naturally human beings are unpredictable and uncontrollable and trying to understand people is a waste of time and energy. Though there is no statically significant predictive relationship among the various styles of leadership and firm performance, it can be argued from the results that leadership in the two banks believe more in democratic leadership approach since it offers motivated work force and financial performance.

\section{Conclusion and Recommendation}

The study concludes that even though there was no statistically significant predictive relationship observed between the three leadership styles and financial performance, the unique contribution of democratic leadership style $(\beta=-.222)$ accounting for more variance in financial performance than autocratic and laissez faire cannot be over looked since the leadership style turn to foster co-operation, motivation, and team spirit among work groups. The researches therefore, recommend that firms especially those in the service industry which want to be more competitive should consider adopting a more democratic leadership style since it is associated with high financial performance and sustainability than autocratic and laissez faire leadership styles.

\section{References}

Argyris, C. (1955). Some Characteristics of Successful Executives. Personnel Journal, June, 50-63.

Barrick, M. R., Day, D. V., Lord, R. G., \& Alexander, R. A. (1991). Assessing the utility of executive leadership. The Leadership Quarterly, 2(1), 9-22. http://dx.doi.org/10.1016/1048-9843(91)90004-L

Bass, B. M. (1985). Leadership and Performance Beyond Expectation. New York: The Free Press.

Bass, B. M., \& Avolio, B. J. (1990). The implications of transactional and transformational leadership for individual, team, and organizational development. Research in Organizational Change and Development, 4(1), 231.

Bass, B. M., Avolio, B. J., Jung, D. I., \& Berson, Y. (2003). Predicting unit performance by assessing transformational and transactional leadership. Journal of applied psychology, 88(2), 207. http://dx.doi.org/10.1037/0021-9010.88.2.207

Bennis, W., \& Nanus, B. (1985). Leadership: The strategies for taking charge. New York.

Bertrand, M., \& Schoar, A. (2003). Managing with Style: The Effect of Managers on Firm Policies. Quarterly Journal of Economics, 118(4), 1169-1208. http://dx. doi.org/10.1162/003355303322552775

Bowsers, D. G., \& Seashore, S. E. (1966). Predicting Organizational Effectiveness with a Four-Factor Theory of Leadership. Administrative Science Quarterly, 11, 238-63. http://dx.doi.org/10.2307/2391247

Burns, J. M. (1978). Leadership. New York: Harper \& Row.

Bycio, P., Hackett, R. D., \& Allen, J. S. (1995). Further Assessments of Bass's (1985) Conceptualization of Transactional and Transformational Leadership. Journal of Applied Psychology, 80(4), 468-78. http://dx.doi.org/10.1037/0021-9010.80.4.468

Choi, S. (2007). Democratic leadership: the lessons of exemplary models for democratic governance. International Journal of Leadership Studies, 2(3), 243-262.

Cole, N. D. (2004). Gender differences in perceived disciplinary fairness. Gender, Work \& Organization, 11(3), 254-277. http://dx.doi.org/10.1111/j.1468-0432.2004.00231.x

Darcy, T., \& Kleiner, B. H. (1991). Leadership for Change in a Turbulent Environment. Leadership and Organization Development Journal, 12(5), 12-16. http://dx.doi.org/10.1108/01437739110004569

Denhardt, R. B., \& Denhardt, J. V. (2003). The New Public Service: an approach to reform. International Review of Public Administration, 8(1), 3-10.

Elley, W. B. (1985). The Elley-Irving socio-economic index 1981 census revision. New Zealand Journal of Educational Studies, 20(2), 115-128.

Fiedler, F. E. (1996). Research on Leadership Selection and Training: One View of the Future. Administrative Science Quarterly, 41, 241-50. http://dx.doi.org/10.2307/2393716

Fry, L. W. (2003). Toward a theory of spiritual leadership. The leadership quarterly, 14(6), 693-727. http://dx.doi.org/10.1016/j.leaqua.2003.09.001

Gabalda, B. (2012). Développement de la notion de propriété: évaluations sociales et morales (Doctoral 
dissertation, Université René Descartes-Paris V.

Gajem, Y. M., Warrick, A. W., \& Myers, D. E. (1981). Spatial dependence of physical properties of a typic torrifluvent soil. Soil Science Society of America Journal, 45(4), 709-715. http://dx.doi.org/10.2136/sssaj1981.03615995004500040007x

Gustainis, J. J. (2004). Autocratic Leadership. Encyclopedia of Leadership, 68-72. http://dx.doi.org/10.4135/9781412952392.n21

Hamidifar, F. (2009). A study of the relationship between leadership styles and employee job satisfaction at Islamic Azad University branches in Tehran. Iran: Islamic Azad University Branches.

Hemphill, J. K., \& Coons, A. E. (1957). Development of the Leader Behaviour Description Questionnaire. In Stogdill, R. M., \& Coons, A. E. (Eds.), Leadership Behaviour: Its Description and Measurement. Columbus, $\mathrm{OH}$ : The Ohio State University, Bureau of Business Research.

Hennessey, J. T. (1998). Reinventing Government: Does Leadership Make the Difference? Public Administration Review, 58(6), 522-32. http://dx.doi.org/10.2307/977579

Hill Jr, R. W., Gordon, A. S., \& \& Kim, J. M. (2004). Learning the lessons of leadership experience: Tools for interactive case method analysis. California: University Of Southern California Marina Del Rey.

Hogan, R., Curphy, G. J., \& Hogan, J. (1994). What we know about leadership: Effectiveness and personality. American psychologist, 49(6), 493. http://dx.doi.org/10.1037/0003-066X.49.6.493

House, R. (1971). A Path-Goal Theory of Leadership. Journal of Contemporary Business, 3, 81-97.

House, R. J., \& Aditya, R. N. (1997). The social scientific study of leadership: quo vadis? Journal of management, 23(3), 409-473. http://dx.doi.org/10.1177/014920639702300306

Howell, J. M., \& Avolio, B. J. (1993). Transformational Leadership, Transactional Leadership, Locus of Control and Support for Innovation: Key Predictors of Consolidated-Business-Unit Performance. Journal of Applied Psychology, 78, 891-902. http://dx.doi.org/10.1037/0021-9010.78.6.891

Hunt, J. G. (1991). Leadership: A new synthesis. Sage Publications, Inc.

Judge, T. A., Piccolo, R. F., \& Ilies, R. (2004). The forgotten ones? The validity of consideration and initiating structure in leadership research. Journal of Applied Psychology, 89, 36-51. http://dx.doi.org/10.1037/0021-9010.89.1.36

Khurana, R. (2002). Searching for a corporate savior: The irrational quest for charismatic CEOs. Princeton University Press.

Koene, B. A., Vogelaar, A. L., \& Soeters, J. L. (2002). Leadership effects on organizational climate and financial performance: Local leadership effect in chain organizations. The Leadership Quarterly, 13(3), 193-215. http://dx.doi.org/10.1016/S1048-9843(02)00103-0

Likert, R. (1932). A Technique for the Measurement of Attitudes. Archives of Psychology, 140.

Likert, R. (1961). New patterns of management. Retrieved from http://www.jstor.org/stable239090

Luthar, H. K. (1996). Gender differences in evaluation of performance and leadership ability. Autocratic vs. democratic managers. Sex Roles, 35(5-6), 337-361. http://dx.doi.org/10.1007/BF01664773

Mahoney, T. A., Jardee, T. H., \& Allan, N. N. (1960). Predicting Managerial Effectiveness. Personnel Psychology, summer, 147-63.

Matsa, D., \& Miller, A. (2011). Chipping away at the glass ceiling: Gender spillovers in corporate leadership. Retrieved from http://ssrn.com/abstract=1709462

McGregor, D. (1960). The human side of enterprise. New York.

Meindl, J. R. (1990). Leadership-An Alternative to The Conventional Wisdom. Research in organizational behavior, 12, 159-203.

Mullins, L. J. (1999). Management and Organizational Behaviour. London: Financial Times.

Nicholls, J. (1988). The Transforming Autocrat. Management Today, March, 114-18.

Northouse, P. G. (2004). Leadership Theory and Practice. Pastoral Psychology, 56(4), 403-411.

Ogbonna, E. (1993). Managing Organizational Culture: Fantasy or Reality? Human Resource Management Journal, 3(2), 42-54. http://dx.doi.10.111/j.1748-8583.1992.tb00309.x 
Ogbonna, E., \& Harris, L. (2000). Leadership style, organizational culture and performance: Empirical evidence from UK companies. International Journal of Human Resources Management, 11(4), 766-788. http://dx.doi.org/10.1080/09585190050075114

Ogbonna, E., \& Harris, L. C. (1998a). Organizational Culture: It's Not What You Think. Journal of General Management, 23(3), 35-48.

Ogbonna, E., \& Harris, L. C. (1998b). Managing Organizational Culture: Compliance or Genuine Change? British Journal of Management, 9, 273-88. http://dx.doi.org/10.1111/1467-8551.00098

O'Reilly, C., Tushman, M., \& Harreld, J. B. (2009). Organizational ambidexterity: IBM and emerging business opportunities.

Porter, L., \& McKibben, L. M. (1988). Management and Development: Drift or Thrust into the 21st Century? New York: McGraw-Hill.

Quick, J. C. (1992). Crafting an Organizational Culture: Herb's Hand at Southwest Airlines. Organizational Dynamics, 21(2), 45-56. http://dx.doi.org/10.1016/0090-2616(92)90063-S

Saari, L., Johnson, T. R., McLaughlin, S. D., \& Zimmerly, D. M. (1988). A Survey of Management Education Practices in the U.S. Companies. Personnel Psychology, 41, 731-43. http://dx.doi.org/10.1111/j.1744-6570.1988.tb00650.x

Sanders, J. O., \& Sanders, J. O. (2007). Spiritual leadership. A commitment to excellence for every believe.

Simms, J. (1997). Beauty Queen. Marketing Business, March, 48-51.

Stogdill, R. M. (1963). Manual for Leadership Description Questionnaire Form XII. Columbus, OH: The Ohio State University Bureau of Business Research.

Tabachnick, L., \& Fidell, B. (1996). Using multivariate statistics. New York: New York Harper Collins College Publishers.

Tannenbaum, R., \& Schmidt, W. H. (1958). How to choose a leadership pattern (pp. 3-12). Institute of industrial relations.

Thorlindsson, T. (1987). The Skipper Effect in the Icelandic Herring Industry. Reykjavik: University of Iceland.

Vroom, V., \& Yetton, P. (1974). Leadership and Decision-Making. Pittsburgh, PA: University of Pittsburgh Press.

Waldman, D. A., Bass, B. M., \& Yammarino, F. (1990). Adding to contingent-reward behavior the augmenting effect of charismatic leadership. Group \& Organization Management, 15(4), 381-394. http://dx.doi.org/10.1177/105960119001500404

White, R., \& Lippitt, R. (1968). Leader behavior and member reaction in three social climates: Group dynamics (pp. 318-385).

Wilson, J. M., George, J., Wellins, R. S., \& Byham, W. C. (1994). Leadership trapeze: Strategies for leadership in team-based organizations. Jossey-Bass Publishers.

Yukl, G. A. (1994). Leadership in Organization. Englewood Cliffs, New Jerseys: Prentice-Hall.

\section{Copyrights}

Copyright for this article is retained by the author(s), with first publication rights granted to the journal.

This is an open-access article distributed under the terms and conditions of the Creative Commons Attribution license (http://creativecommons.org/licenses/by/3.0/). 